\title{
Skunks as Scavengers
}

\author{
By E. Wiley, Scltcoats
}

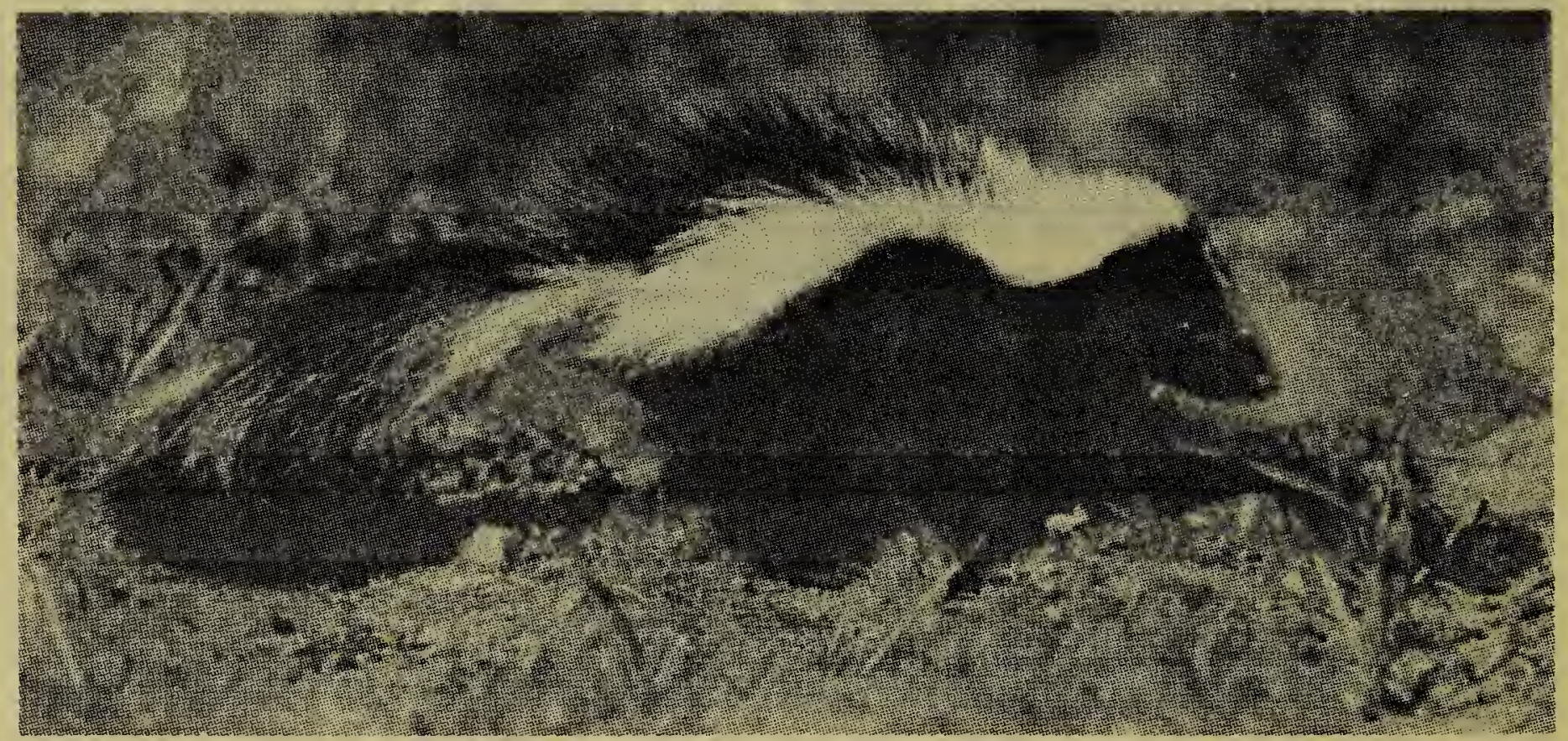

In the last issue of the BLUE JAY, Mr. C. C. Shaw asks if the skunk is a scavenger.

At certain times of the year he is, especially in the fall when other food is getting scarce. It is then he feeds on rabbits killed by cars and searches out ducks that have died in the marshes. His favorite denning site is an old badger hole in a snowberry patch, where there is plenty of dead grass handy. There is logic in choosing Snowberries, as the snow will drift in there and keep him warm. He takes a supply of dead grass into the den by travelling backwards, scraping it along with his front feet.

Sometimes a large buck skunk may spend the winter with a harem of as many as a dozen beautiful skunk ladies -- while the lesser lights of the district have no choice but to sleep alone.

Their den is scrupulously clean. All they do during the winter is sleep and look after the air conditioning of their home. This is done by pushing a little more or a little less of the dead grass into the entrance ot the den.

They do not eat anything from November until late February or March when the age-old urge to reproduce causes the young bucks to sally forth in search of company. Exercise makes them hungry; once again they become scavengers and any-thing "goes". Later in the spring they turn to eggs, to young birds and to young mice. They become very adept at pilfering young birds from beneath their mothers, at night.

Then comes the busy season -young must be reared and heavy layers of fat laid on for the coming winter. Feed is plentiful: frogs, snails, beetles bugs, grasshoppers, minnows, etc. When fall comes circumstances force them to become scavengers again.

\section{By Arthur Ward, Swift Current}

In answer to the query of Cliff Shaw as to the scavenger propensities of the skunk, in our experience it has been observed to be partial to anything on the decayed side. It will pass up fresh eggs for those that are tainted. It has a keen scence of smell and will dig up dead cats and hens and even dig down to a dead pig.

Having disposed of the parents, we fed four young ones on milk in a saucer. They would come in answer to a whistle -- lap up the milk on the doorstep, then go off and hide until the next meal. If handled gently their manners are those of a kitten. Two of the young skunks we fed are now in the famous Walter Gurney Mus eum at Lethbridge. 